\title{
Gastric Mammalian Target of Rapamycin Signaling Contributes to Inhibition of Ghrelin Expression Induced by Roux-En-Y Gastric Bypass
}

\author{
Danjie Lia Shaojian Lia Qinling Pan ${ }^{a}$ Hening Zhai ${ }^{b}$ Miao Peng ${ }^{a}$ \\ Xuanxuan Wang ${ }^{c}$ Geyang Xu ${ }^{a}$ \\ aDepartment of Physiology, School of Medicine, Jinan University, Guangzhou, bEndoscopy Center, The \\ First Affiliated Hospital of Jinan University, Guangzhou, 'Department of Emergency Medicine, The First \\ Affiliated Hospital of Jinan University, Guangzhou, China
}

\section{Key Words}

Ghrelin $\cdot \mathrm{mTOR} \cdot \mathrm{RYGB} \cdot$ Gastric fundus

\begin{abstract}
Background/Aims: Roux-en-Y Gastric Bypass, RYGB, is the most effective strategy to control body weight in morbid obesity. RYGB leads to rapid improvement of glycemic status and weight loss, which are largely attributed to the alteration of gastrointestinal hormones including ghrelin. The current study examined potential mechanisms of altered ghrelin synthesis after RYGB. Methods: Gastric mammalian target of rapamycin (mTOR) signaling, ghrelin synthesis and secretion were determined in lean or obese male mice with or without RYGB operation, as well as in obese patients pre- and post-RYGB surgery. Ghrelin expression and mTOR signaling were investigated by western blotting and immunohistochemistry. Ghrelin mRNA levels were detected by real-time PCR. Plasma ghrelin was measured by enzyme immunoassay. Results: mTOR activity in the gastric fundus was significantly lower than in the forestomachs. Both of them were decreased after $24 \mathrm{~h}$ fasting. A significant negative correlation was found between gastric levels of phospho-S6 (phospho-S6 ribosomal protein) and proghrelin during changes of energy status. mTOR activity was activated, whereas ghrelin expression was inhibited by Roux-en-Y Gastric Bypass in both rodents and human beings. Increment of ghrelin synthesis and decline of mTOR signaling induced by rapamycin were significantly reversed by RYGB in both lean and obese mice. Administration of Ad-S6K1 (adenovirus-mediated p70 ribosomal protein subunit 6 kinase 1) from tail vein suppressed the expression of ghrelin in RYGBoperated mice relative to control animals. Conclusion: mTOR is therefore a gastric fuel sensor whose activity is linked to the regulation of ghrelin after Roux-en-Y Gastric Bypass.

D. Li and S. Li contributed equally to this work.

Geyang Xu

Department of Physiology, School of Medicine, Jinan University

601 Huangpu Avenue West, Tianhe District, Guangzhou, Guangdong, 510632 (China)

Tel. 0086-20-85220260, Fax 0086-20-85221343, E-Mail xugeyangliang@163.com
\end{abstract}

KARGER 


\section{Cellular Physiology Cell Physiol Biochem 2018;51:664-680

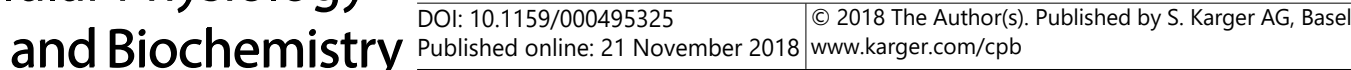 \\ Li et al.: Gastric mTORC1 Signaling and Ghrelin After RYGB}

\section{Introduction}

The obesity epidemic has grown in severity over the past several decades and is now a worldwide public health priority [1]. Long-term studies show that bariatric surgery causes significant weight loss, recovery from type 2 diabetes and expeditious metabolic improvements [2-4]. Roux-en-Y Gastric Bypass (RYGB) is a popular and efficacious form of bariatric operation [5-7]. In RYGB, the stomach is divided into a small upper pouch and a much larger lower remnant pouch. In addition, the jejunum is also transected, and the distal portion of the small intestine (mid-jejunum and ileum) is connected directly to the small upper pouch so that meal contents bypass the lower stomach and the upper small bowel $[8,9]$. The weight loss and improvement of glycemic status after RYGB are thought, in a large part, to be the results of RYGB-induced rerouting of nutrients, which in turn to alter the secretion of gastrointestinal hormones, such as glucagon-like peptide-1, peptide YY, cholecystokinin, and ghrelin [10-14].

Ghrelin is a growth-hormone-releasing peptide that was firstly purified from the stomach [15]. Gastric X/A like cells have been identified as the predominant source of circulating ghrelin $[16,17]$. Acylated ghrelin and des-acyl ghrelin are two major forms of ghrelin peptide in gastrointestinal tract. Acyl-ghrelin is octanoylated at serine- 3 by ghrelin 0 -acyltransferase (GOAT), which allows ghrelin to bind to its receptor, the growth hormone secretagogue receptor 1a (GHSR-1a), to exert its biologic actions $[18,19]$. Another form of ghrelin, des-acyl ghrelin, also has been shown to exert some biological activities, although these presumably occur via GHSR-independent mechanisms [20]. Ghrelin is best known for its orexigenic and glucoregulatory actions. Administered acyl-ghrelin potently stimulates appetite by triggering receptors in the arcuate nucleus that include the orexigenic neuropeptide Y (NPY) and agouti-related protein (AgRP) neurons [21-25]. Ghrelin increases fasting blood glucose through suppression of insulin secretion [21, 26, 27]. Ghrelin levels show a preprandial rise and a postprandial fall [28]. Unexpectedly, ghrelin levels are negatively correlated with body weight in humans and rodents $[29,30]$. Literatures illustrate that RYGB operation is accompanied by varying plasma ghrelin, either increased, decreased or unchanged ghrelin levels, depending on the procedure and monitoring time [14]. Although the secretion of ghrelin after gastrointestinal weight-loss surgeries has been the matter of numerous studies, to the best of our knowledge, only few reported the synthesis of ghrelin after RYGB.

Ninety percent of ghrelin is produced by the stomach and duodenum tissues [16, 21]. As the gastrointestinal tract is directly remolded by RYGB, we speculated that ghrelin synthesis may be disturbed following this operation. The molecular mechanisms by which postoperative X/A like cells sense fuel status at the organism level and regulate ghrelin production are currently unknown. Our previous studies indicate that mammalian target of rapamycin (mTOR) is a gastric fuel sensor whose activity is linked to the regulation of energy intake through ghrelin [31]. mTOR integrates signals from nutrients, growth factors, cellular energy stores, and other cues to control a variety of important cellular processes including growth, proliferation, differentiation. The mTOR pathway is a central regulator of metabolism, with important roles in the function of tissues including liver, muscle, white and brown adipose tissue, and the brain [32]. Moreover, the activity of mTOR is dysregulated in human diseases, such as diabetes, obesity, and certain cancers [33]. The goal of this study is to investigate mechanisms that contribute to altered ghrelin levels after RYGB. We hypothesized that ghrelin levels are altered through the change of gastric mTOR signaling after RYGB operation. We tested this hypothesis in both mice and human subjects with obesity and after weight loss induced by RYGB. Here, we present evidence that gastric mammalian target of rapamycin signaling contributes to inhibition of ghrelin production induced by Roux-en- $Y$ Gastric Bypass. Our data identify gastric specific regulation of ghrelin gene expression as a new mechanism of action for mTOR after RYGB operation, thus expanding its interest as a potential target for the treatment of obesity. 


\section{Cellular Physiology Cell Physiol Biochem 2018;51:664-680 and Biochemistry \begin{tabular}{l|l} 
DOI: 10.1159/000495325 & (c) 2018 The Author(s). Published by S. Karger AG, Basel \\
www.karger.com/cpb
\end{tabular}}

Li et al.: Gastric mTORC1 Signaling and Ghrelin After RYGB

\section{Materials and Methods}

\section{Materials}

Rapamycin and DMSO were purchased from Sigma Chemical Co. (St. Louis, MO). Rabbit anti-PhosphomTOR (Ser2448), anti-Phospho-p70 S6 Kinase (Thr389), anti-Phospho-S6 (Ser235/236), anti-mTOR, anti-p70 S6 Kinase, anti-S6 antibodies and mouse monoclonal anti- $\beta$-actin were from Cell Signaling Technology (Beverly, MA). Mouse anti-ghrelin was from Abcam Inc. (Cambridge, MA). Horseradish peroxidase-conjugated, donkey anti-Rabbit IgG and donkey anti-Mouse IgG were purchased from Jackson ImmunoResearch (West Grove, PA). Immobilon western chemiluminescent HRP substrate was from Millipore (Temecula, CA). Trizol reagent and the reverse transcription (RT) system were from Promega Inc. (Madison, WI). Ghrelin enzyme immunoassay kit was from Phoenix Pharmaceuticals Inc. (Burlingame, CA). Regular chow (NCD: $3.85 \mathrm{kcal} / \mathrm{g}, 10 \%$ fat, $20 \%$ protein, 70\% carbohydrate, formula D12450B) and high-fat $\operatorname{diet}(5.24 \mathrm{kcal} / \mathrm{g}$, 60\% fat, 20\% protein, 20\% carbohydrate, formula D12492) were from Research Diets, Inc. (New Brunswick, NJ).

\section{Animals and treatments}

Male C57BL/6J mice were housed and maintained in a regulated environment $\left(24^{\circ} \mathrm{C}, 12\right.$-h light, 12 -h dark cycle with lights on at 07:00 and off at 19:00). Regular chow, high-fat diet (HFD) and water were available ad libitum unless specified otherwise. Animals used in this study were handled in accordance with the Guide for the Care and Use of Laboratory Animals published by the National Institutes of Health (NIH Publications No. 8023, revised 1978). All animal protocols were approved by the Animal Care and Use Committee of Jinan University. To examine the effects of fasting on mTOR signaling and ghrelin production in mouse forestomach and fundus, 12 -week-old C57BL/6J male mice were fed or fasted for $24 \mathrm{~h}$. To determine the effects of RYGB on ghrelin production under alteration of gastric mTOR signaling, 16-week-old C57BL/6J male mice were randomly divided into RYGB- and sham-operated group. After 4-week recovery, mice received i.p. injection with DMSO or rapamycin $(1 \mathrm{mg} / \mathrm{kg})$, or administrated with Ad-GFP $\left(10^{9} \mathrm{pfu}\right)$ or Ad$\mathrm{S} 6 \mathrm{~K} 1\left(10^{9} \mathrm{pfu}\right)$ from tail veins for 9 consecutive days before sacrifice.

\section{Surgical procedures and postoperative care}

RYGB and sham surgeries were performed as previously described [34, 35]. Animals were fasted 4 to 6 hours before operation. Standard aseptic procedures were used throughout.

For RYGB, firstly, a small gastric pouch with a volume of approximately $5 \%$ of the normal gastric volume was made, then the pouch was anastomosed with the open end of the jejunum. The jejunum was transected about $2 \mathrm{~cm}$ distal to the ligament of Treitz, and the distal end was brought up to the gastric pouch for endto-end anastomosis. For the jejuno-jejunostomy, a longitudinal slit was made on the antimesenteric side of the jejunum at $6 \mathrm{~cm}$ distal to the site of gastrojejunostomy, and the proximal end of the jejunum was joined in an end-to-side anastomosis. Before closing of the abdominal cavity, the intestine was arranged in an "S" position to avoid intestinal obstruction.

For the sham operation, the perigastric ligaments were cut, and then a $3 \mathrm{~mm}$ incision was made in the stomach wall and closed with a titanium clip. In addition, the jejunum was transected $2 \mathrm{~cm}$ distal to the ligament of Treitz. Post-operative care was performed as previously described [36].

\section{Measurement of body weight and food intake}

Body weight was measured daily. Food intake was measured in mice from day 29 to day 35 after surgery. Average daily intake was calculated with taking spillage into account.

\section{Western blot analysis}

The tissues were homogenized on ice in the lysis buffer. After centrifugation and protein quantification, proteins were loaded onto SDS-PAGE gels, and then transferred to nitrocellulose membranes. The membranes were incubated in $5 \%$ nonfat dry milk in TBST for $1 \mathrm{~h}$ at room temperature, followed by incubation overnight at $4^{\circ} \mathrm{C}$ with the primary antibodies. The antibodies were detected using 1:10, 000 horseradish peroxidaseconjugated, donkey anti-Rabbit IgG and donkey anti-Mouse IgG (Jackson ImmunoResearch, PA). A western blotting luminol reagent was used to visualize bands corresponding to each antibody. The band intensities were quantitated by Image J software. 


\section{Cellular Physiology Cell Physiol Biochem 2018;51:664-680 and Biochemistry \begin{tabular}{l|l} 
DOI: 10.1159/000495325 & (c)18 The Author(s). Published by S. Karger AG, Basel \\
wuww.karger.com/cpb
\end{tabular}

Table 1. List and sequences of primers used in RT-PCR experiments

\begin{tabular}{lccc}
\hline Gene name & Primer direction & Sequence & Accession number(s) \\
\hline \multirow{2}{*}{ Mouse Ghrelin } & Forward: & CCATCTGCAGTTTGCTGCTA & \multirow{2}{*}{ No.XM_006506446.3 } \\
Mouse Ghrelin & Reverse: & GCAGTTTAGCTGGTGGCTTC & \\
O-acyltransferase & Forward: & GTGAGTGCTGGAGCTGGACTG & No.XM_006509106.3 \\
Mouse $\beta$-actin & Forward: & TGAGCCACAGAGCTGTGCTTC & \\
& Reverse: & ATCTGGCACCACACCTTC & No.NM_007393.5 \\
Human Ghrelin & Forward: & AAAGATGGAGGTCAAGCAGAAGG & \multirow{2}{*}{ No.XM_017006613.1 } \\
& Reverse: & TCCCAGAGGATGTCCTGAAGAA & \\
Human TFIIB & Forward: & ACCAGCCGTTTGGATGCTC & No.XR_001737129.1 \\
& Reverse: & CCCACATCAATAACCCGGTC & \\
\hline
\end{tabular}

Table 2. Clinical and biochemical characteristics of patients. Anthropometric data. All patients undertook a 12-h fasting before blood collection for biochemical tests. Clinical biochemistry testing was conducted by Hitachi Automatic Biochemistry Analyzer (Hitachi High-technologies Corporation, Tokyo). ALT, Alanine aminotransferase; AST, Aspartate transaminase; BMI, body mass index; HDL, high-density lipoprotein; LDL, low-density lipoprotein; TG, triglyceride. Data are mean \pm SEM. Differences between groups were analyzed by Mann-Whitney U rank sum test. $n=6$. $P$ value 1 represents lean participants vs. obese participants; $P$ value 2 represents post-RYGB participants vs. obese participants

\begin{tabular}{lccccc}
\hline Parameter & Lean & Obese & Post-RYGB & P value 1 & P value 2 \\
\hline Age (year) & $40.33 \pm 4.65$ & $35.27 \pm 3.16$ & $32.00 \pm 0.71$ & 0.37 & 0.55 \\
Body weight (kg) & $64.94 \pm 3.28$ & $120.4 \pm 12.67$ & $72.64 \pm 3.79$ & $<0.01$ & 0.02 \\
BMI (kg/m²) & $23.19 \pm 0.95$ & $44.34 \pm 3.44$ & $26.78 \pm 1.55$ & $<0.0001$ & $<0.01$ \\
Glucose (mmol/l) & $5.05 \pm 0.28$ & $7.04 \pm 0.36$ & $5.55 \pm 0.33$ & $<0.01$ & 0.02 \\
TG (mmol/l) & $1.51 \pm 0.12$ & $3.04 \pm 0.48$ & $1.48 \pm 0.29$ & 0.02 & 0.05 \\
Cholesterol (mmol/l) & $4.82 \pm 0.27$ & $5.71 \pm 0.57$ & $4.78 \pm 0.64$ & 0.15 & 0.36 \\
LDL (mmol/l) & $3.58 \pm 0.48$ & $3.14 \pm 0.31$ & $2.12 \pm 0.10$ & 0.44 & 0.10 \\
HDL (mmol/l) & $1.36 \pm 0.17$ & $0.90 \pm 0.06$ & $1.20 \pm 0.22$ & 0.02 & 0.09 \\
ALT (U/L) & $21.83 \pm 1.82$ & $68.88 \pm 25.56$ & $55.00 \pm 18.59$ & 0.14 & 0.73 \\
AST (U/L) & $21.14 \pm 1.57$ & $35.29 \pm 8.17$ & $31.33 \pm 2.60$ & 0.12 & 0.77 \\
\hline
\end{tabular}

RNA extraction, quantitative real-time PCR

For gene expression analysis, RNA was isolated from mouse and human tissues using Trizol and reverse-transcribed into cDNAs using the First-Strand Synthesis System for RT-PCR kit. SYBR Green-based real-time PCR was performed using the Mx3000 multiplex quantitative PCR system (Stratagene, La Jolla, CA). Triplicate samples were collected for each experimental condition to determine relative expression levels. Sequences for the primer pairs used in this study were shown in Table 1.

\section{Measurements of ghrelin}

Blood samples were collected after anesthesia in the presence of aprotinin $(2 \mu \mathrm{g} / \mathrm{ml})$ and EDTA $(1 \mathrm{mg} /$ $\mathrm{ml}$ ). $\mathrm{HCl}$ was added into plasma for a final concentration of $0.1 \mathrm{~mol} / \mathrm{l}$ to prevent ghrelin from degradation. Plasma was harvested and stored at $-80^{\circ} \mathrm{C}$ before use. Total ghrelin was measured using an enzyme immunoassay kit according to the manufacturer's instruction.

\section{Immunohistochemistry}

Gastric mucosal biopsies were postfixed in 4\% paraformaldehyde, dehydrated, embedded in wax, and sectioned at $6 \mu \mathrm{m}$. Paraffin-embedded sections were dewaxed, rehydrated, and rinsed in PBS. After boiling for $10 \mathrm{~min}$ in $0.01 \mathrm{~mol} / \mathrm{l}$ sodium citrate buffer ( $\mathrm{pH}$ 6.0), sections were blocked in $5 \%$ goat preimmune serum in PBS for $1 \mathrm{~h}$ at room temperature and then incubated overnight with rabbit phospho-S6 (Ser235/236) $(1: 100)$ or mouse monoclonal antibody to ghrelin $(5 \mu \mathrm{g} / \mathrm{ml})$. Tissue sections were then incubated at $22^{\circ} \mathrm{C}$ for $2 \mathrm{~h}$ with the following secondary antibodies: Goat anti-Mouse fluorescein isothiocyanate-conjugated IgG (1:50) or Dylight 594 Affinipure Donkey anti-Rabbit IgG (1:100). Photomicrographs were taken under a confocal laser-scanning microscope (Leica, Germany). 


\section{Cellular Physiology Cell Physiol Biochem 2018;51:664-680

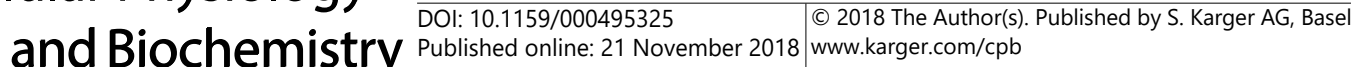

Li et al.: Gastric mTORC1 Signaling and Ghrelin After RYGB

Recruitment of human subjects and collection of gastric mucosa

Six obese male participants with type 2 diabetes, six one-year post-RYGB patients and six normal glycemic participants were enrolled in the study. All participants have not taken any drugs one week before biopsy collection. Individuals were excluded if they had a history of diabetic ketoacidosis, uncontrolled type 2 diabetes (HbA1c $>12 \%)$, gastrointestinal disease, malignant disease within five years, significant cardiopulmonary or renal disease, active eating disorder, drug and/or alcohol abuse, impaired mental status. Anthropometric data are provided in Table 2. Participation in this study was voluntary, and written informed consent was obtained from each participant. The research was conducted ethically in accordance with the World Medical Association Declaration of Helsinki. All protocols were approved by the Research Ethics Committee of The First Affiliated Hospital of Jinan University. All participants were fasted for 12 $\mathrm{h}$ before biopsy collection. Mucosal biopsies were taken from sedated participants using a gastroscope (GIF-HQ290; Olympus). Tissue samples were extracted for protein and RNA or for immunohistochemistry, respectively.

\section{Statistical analysis}

All data are expressed as mean values \pm SEM. Differences were significant with $\mathrm{p}$ values less than 0.05. The correlation was determined by Pearson analysis. Mann-Whitney U rank sum test and Factorial design analysis of variance (ANOVA) were conducted where appropriate and indicated in figure legends.

\section{Results}

Reciprocal effects of fasting on gastric mTOR signaling and ghrelin production in mouse forestomachs and gastric fundus

To examine the effects of fasting on mTOR signaling and ghrelin production in both forestomachs and gastric fundus, 12 -week-old male C57BL/6J mice were divided into two groups, a control group in which animals were fed ad libitum and a group in which mice were fasted for 24h. Phosphorylation of mTOR and its downstream targets S6K and S6 [37, 38], which were reduced by $24 \mathrm{~h}$ fasting in mouse forestomachs and fundus. More interestingly, the activity of mTOR signaling in the forestomachs was significantly higher than in the fundus (Fig. 1A). Ghrelin protein levels were stimulated by fasting (Fig. 1A). A significant negative correlation was found between gastric levels of phospho-S6 and proghrelin (Pearson's $r=$ -0.66; P = 0.0007) (Fig. 1B). Ghrelin and ghrelin O-acyltransferase (GOAT) mRNA levels were found to be mainly expressed in fundus. Both of them were significantly activated by $24 \mathrm{~h}$ fasting (Fig. 1C and D).

Effects of rapamycin and RYGB on gastric mTORC1 signaling, ghrelin production in lean and DIO mice

Although literatures demonstrate that ghrelin is changed after RYGB operation, the mechanisms still need to be further explored. Our previous studies show that the MTOR signaling system regulates gastric mucosal production of ghrelin [31]. We firstly hypothesized that RYGB inhibited ghrelin production through mTOR signaling. If mTOR signaling is linked to the production of ghrelin, altered mTOR activity would be predicted to change the production and secretion of ghrelin after RYGB. The effects of rapamycin, a well-characterized mTOR inhibitor, were firstly examined in C57BL/6J mice. Male C57BL/6J mice fed with normal chow diet were divided into 4 groups: sham-operated mice receiving dimethyl sulfoxide (DMSO), sham group receiving rapamycin $(1 \mathrm{mg} / \mathrm{kg}$, i.p. injection for 9 days), RYGB-operated mice receiving either vehicle or rapamycin. Rapamycin stimulated ghrelin and GOAT expression in gastric fundus in sham-operated mice, but not in forestomachs (Fig. 2B, D, E). mTOR activity in gastric pouches and residual stomachs was stimulated by RYGB. Attenuation of mTOR activity induced by rapamycin was reversed by RYGB (Fig. 2B). The increase of gastric mTOR signaling in post-operative mice was associated with a significant decline of gastric ghrelin contents and GOAT mRNA expression versus sham-operated animals (Fig. 2B, D, E). A significant negative correlation was found between gastric levels of phospho-S6 and proghrelin (Pearson's $r=-0.53 ; \mathrm{P}=0.0004$ ) (Fig. 2C). 


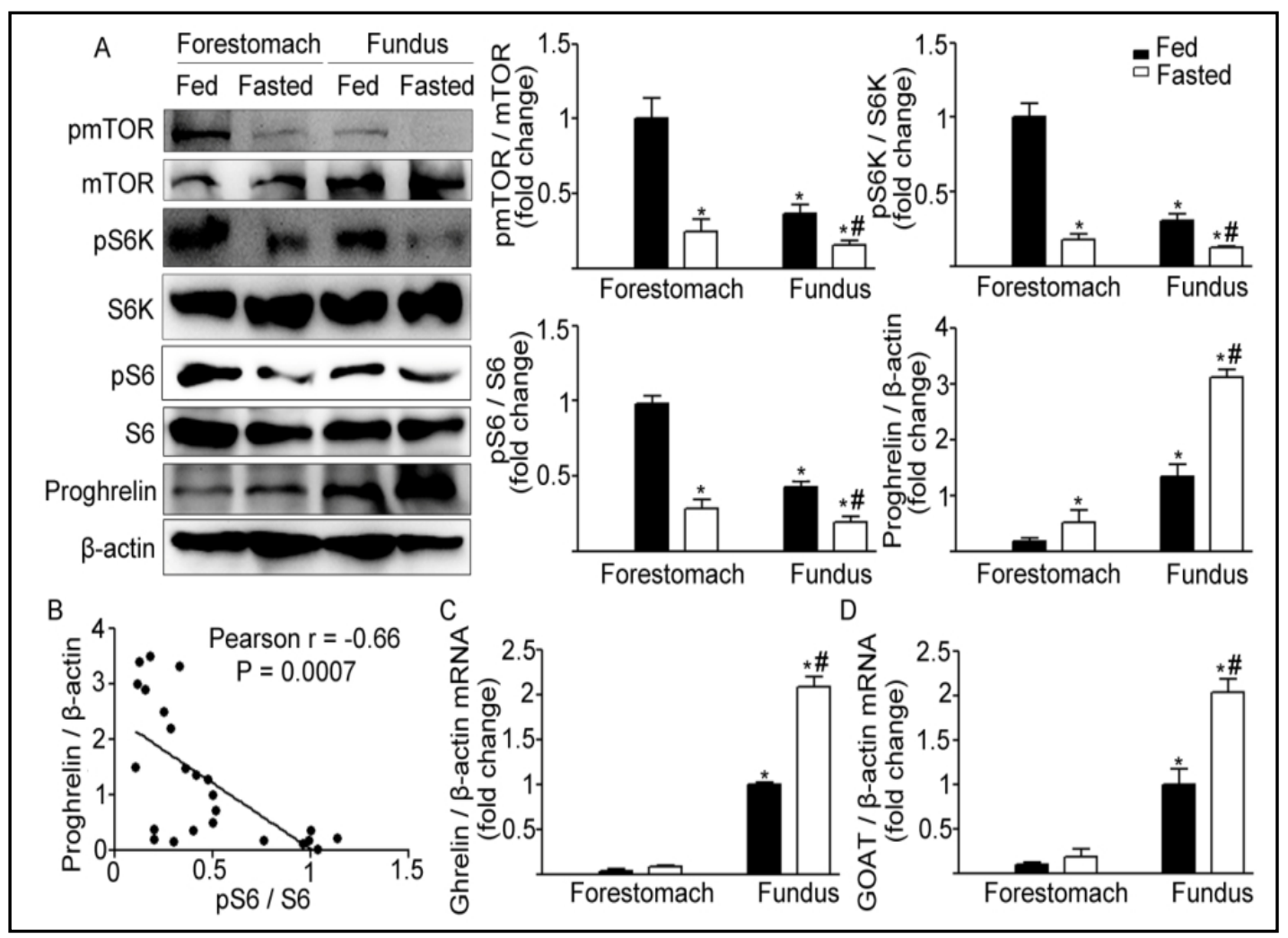

Fig. 1. Modulation of mTOR signaling and ghrelin expression by energy status in forestomachs and gastric fundus in C57BL/6J mice. (A) Representative western blot from fed mice or mice fasted for $24 \mathrm{~h}$ (12-weekold male mice, $\mathrm{n}=6$ for each group). Phospho-mTOR (pmTOR), phospho-S6K (pS6K), phospho-S6 (pS6), and proghrelin from mouse forestomachs and gastric fundus were blotted as described in Materials and Methods. $\beta$-actin and mTOR, S6K, S6 were used as loading controls. Quantification of image analysis of mTOR, S6K, S6 phosphorylation and proghrelin expression is expressed as mean values \pm SEM. (B) Correlation between protein levels of ghrelin and pS6 was determined by Pearson analysis. (C, D) Results of quantitative PCR analysis of ghrelin (C) and GOAT (D) mRNA are expressed as fold increase from fed condition using $\beta$-actin as a loading control. $n=6,{ }^{*} P<0.05$ vs. forestomachs in the fed state. ${ }^{*} P<0.05$ vs. mouse fundus in the fed state. Statistical differences were assessed by factorial design analysis of variance (ANOVA).

Next experiments were performed on high-fat diet-induced obese (DIO) mice. DIO mice were divided into sham or RYGB-operated mice with or without i.p. injection of rapamycin. Consistent with observations in standard diet-fed mice, rapamycin restrained while RYGB enhanced gastric mTOR signaling activity in DIO mice. Moreover, the decline of mTOR signaling activity and increment of ghrelin synthesis induced by rapamycin were reversed by RYGB (Fig. 3). Pearson's analysis demonstrated a negative correlation between the change of ghrelin synthesis and phosphorylation of S6 (Fig. 3B).

As expected, RYGB reduced body weight in both normal chow diet and high-fat diet-fed mice (Fig. 4A and C). Consistent to the study of Hao et al. [34], increased intake of either standard diet or high-fat diet in RYGB mice was observed when compared with shamoperated mice. In addition, rapamycin stimulated food intake in sham-operated mice but not in RYGB animals (Fig. 4B, D). The change of energy intake was associated with ghrelin secretion (Fig. 4E). 


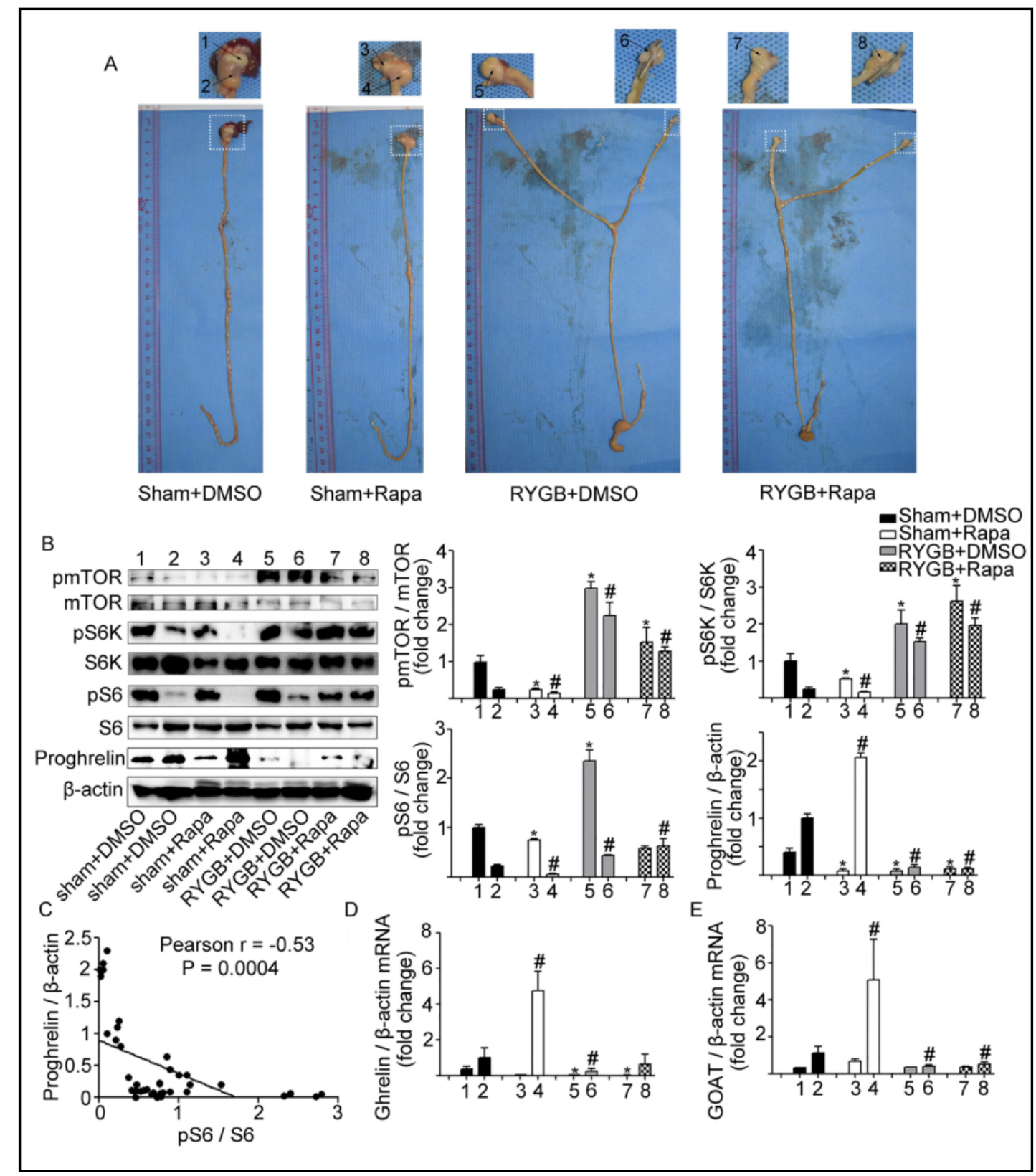

Fig. 2. Effects of rapamycin and RYGB on gastric mTORC1 signaling and ghrelin production in lean C57BL/6J mice. (A) Post-mortem representative macroscopic photomicrographs of gastrointestinal tract of shamoperated animals receiving DMSO or rapamycin, RYGB mice receiving DMSO or rapamycin (4-5-month-old male mice, $n=5$ per group). Forestomach (1) and fundus (2) from sham + DMSO group; forestomach (3) and fundus (4) from sham + rapamycin group; gastric pouch (5) and residual stomach (6) from RYGB receiving DMSO; gastric pouch (7) and residual stomach (8) from RYGB receiving rapamycin. (B) Representative western blot from sham-or RYGB-operated mice that received i.p. injection of DMSO or rapamycin (Rapa, $1 \mathrm{mg} / \mathrm{kg}$ ). pmTOR, pS6K, pS6 and proghrelin were detected using specific antibodies. $\beta$-actin, mTOR, S6K and S6 were used as loading controls. Quantification of image analysis is expressed as mean values \pm SEM. (C) Correlation between protein levels of ghrelin and pS6 was determined by Pearson analysis. Results of quantitative PCR analysis of ghrelin (D) and GOAT mRNA (E) are expressed as fold increase from control using $\beta$-actin as loading control. $\mathrm{n}=5,{ }^{*} \mathrm{P}<0.05$ vs. forestomachs from sham mice receiving $\mathrm{DMSO}$. ${ }^{*} \mathrm{P}<0.05$ vs. fundus from sham mice receiving DMSO, assessed by factorial design analysis of variance (ANOVA). 


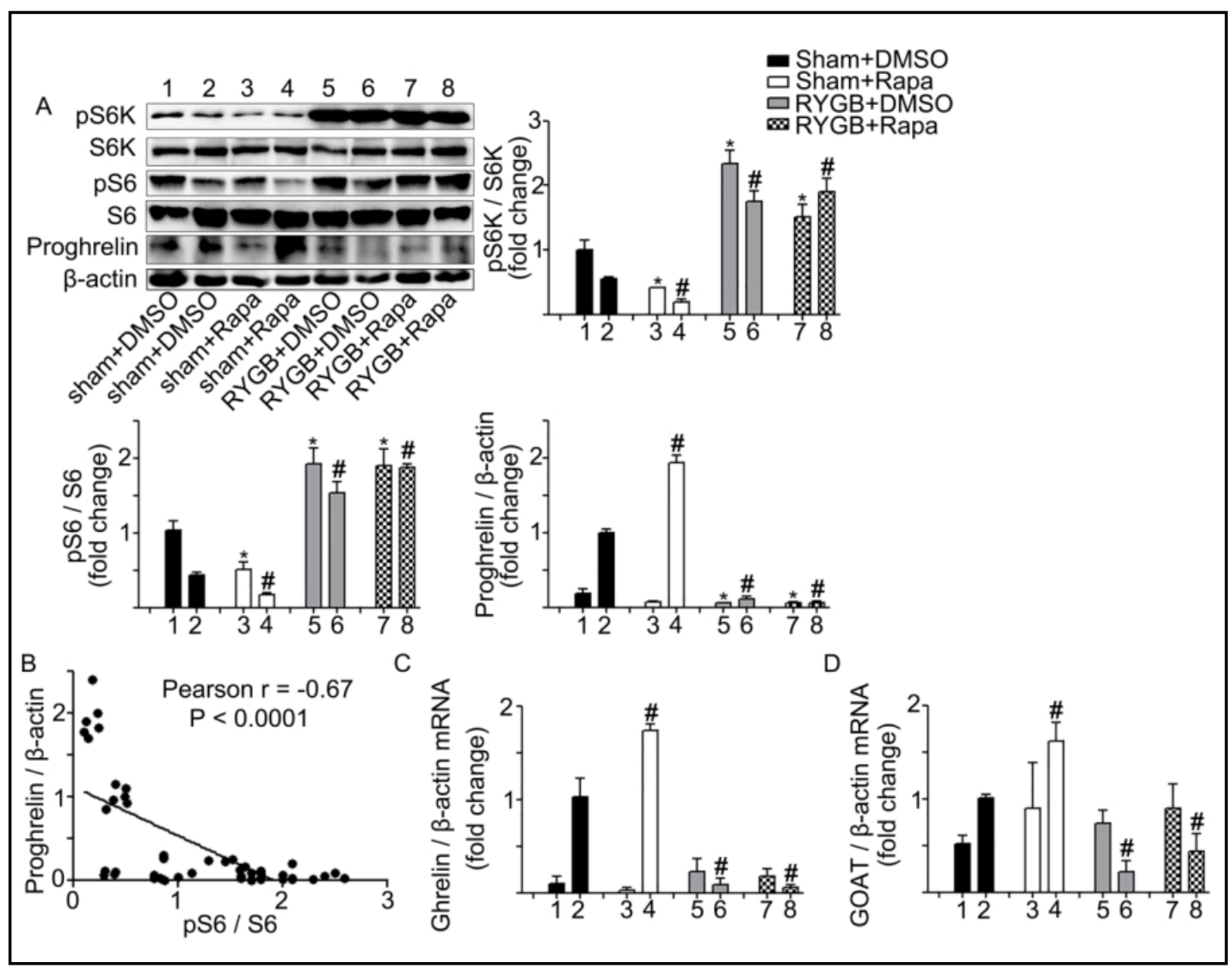

Fig. 3. Effects of rapamycin and RYGB on gastric mTORC1 signaling and ghrelin production in DIO mice. Representative western blot (A), Pearson analysis (B), results of quantitative PCR analysis of ghrelin (C) and GOAT (D) mRNA are expressed as fold increase in DIO mice (4-5-month-old mice, $n=6$, mice were fed a high fat diet for 4 months started around weaning) subjected to different treatments using $\beta$-actin as loading control. ${ }^{*} \mathrm{P}<0.05$ vs. forestomachs from sham mice receiving $\mathrm{DMSO}$. ${ }^{*} \mathrm{P}<0.05$ vs. fundus from sham mice receiving DMSO, assessed by factorial design ANOVA.

\section{Effects of Ad-S6K1 on RYGB-elicited alteration of gastric mTOR signaling and ghrelin} production in DIO mice

Because inhibition of mTOR signaling in the gastric mucosa leads to stimulation of ghrelin expression, it is expected that activation of mTOR signaling in the gastric mucosa would suppress the production of ghrelin. Tail vein administration of Ad-S6K1 $\left(10^{9} \mathrm{pfu}\right)$ significantly stimulated both phospho-p70 S6 Kinase and phospho-S6 levels (Fig. 5A), while inhibited gastric ghrelin mRNA, GOAT mRNA levels and gastric proghrelin content in shamoperated mice. RYGB combined with administration of Ad-S6K1 also significantly stimulated mTOR signaling activity and inhibited ghrelin expression compared to sham-operated mice receiving Ad-GFP (Fig. 5).

RYGB reduced body weight in both Ad-GFP and Ad-S6K1 treated mice (Fig. 6A). Tail vein administration of Ad-S6K1 (10 $9 \mathrm{pfu})$ inhibited energy intake in sham-operated mice but not in RYGB animals (Fig. 6B). The change of food intake in mice with different treatments was associated with ghrelin secretion (Fig. 6C). 


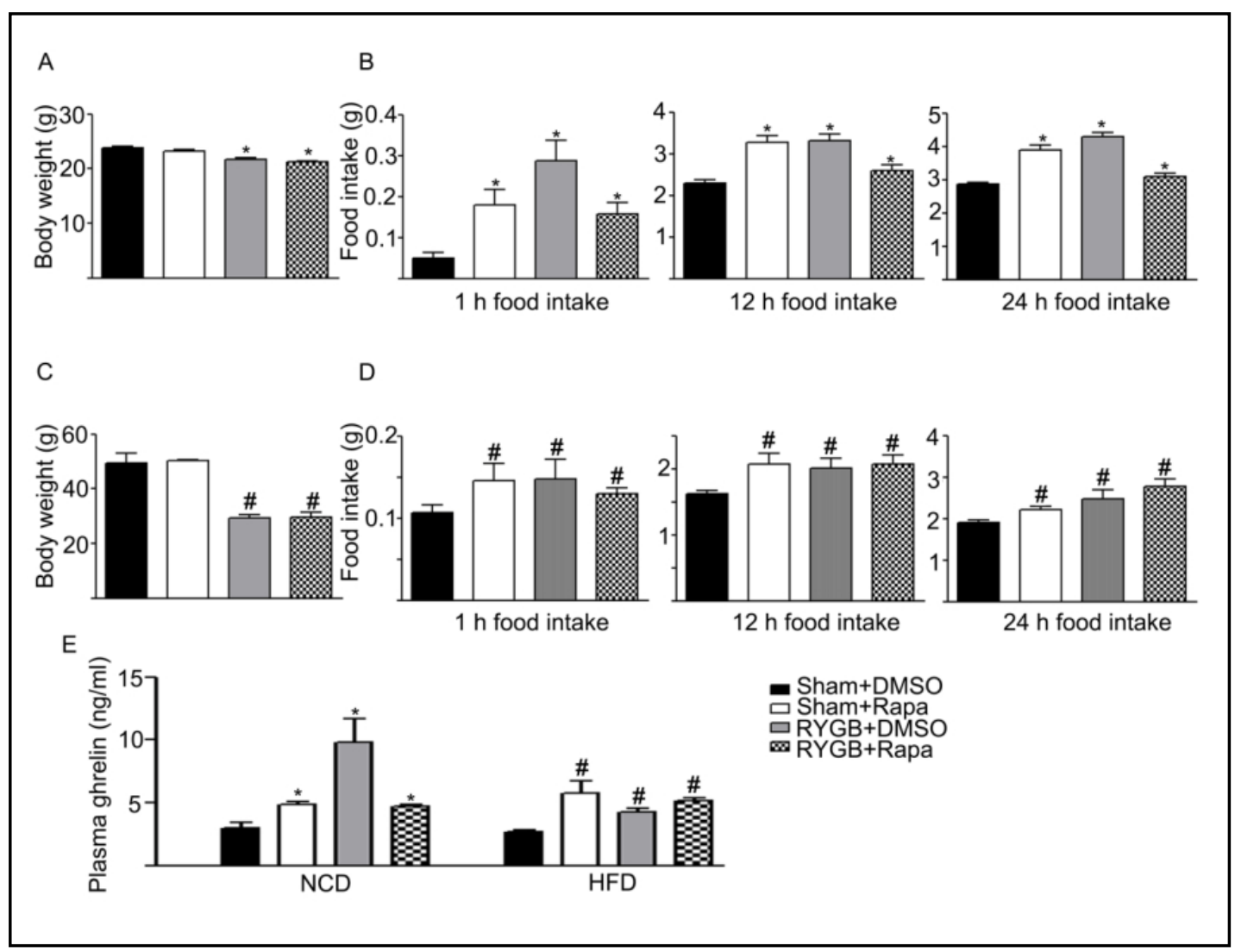

Fig. 4. Effects of RYGB on body weight, food intake and ghrelin secretion under systemic administration of rapamycin. (A, B) For normal chow diet fed mice (4-5-month-old mice, $n=5$ ), (A) body weight, (B) 1h, 12h, $24 \mathrm{~h}$ food intake. (C, D) For high-fat diet fed mice (4-5-month-old mice, $\mathrm{n}=6$ ), (C) body weight, (D) $1 \mathrm{~h}, 12 \mathrm{~h}$, $24 \mathrm{~h}$ food intake. (E) Plasma total ghrelin in different group mice was measured as described in Materials and Methods, and results are expressed as mean values $\pm \mathrm{SEM}$. ${ }^{*} \mathrm{P}<0.05$ vs. sham-operated normal mice receiving DMSO. ${ }^{*} \mathrm{P}<0.05$ vs. sham-operated DIO mice receiving DMSO. Statistical differences were evaluated by factorial design analysis of variance (ANOVA).

RYGB activated gastric mTOR signaling and inhibited ghrelin expression in human beings

We further examined the effects of RYGB on gastric mTOR signaling activity and ghrelin expression in human subjects. As shown in Fig. 7A, levels of pS6K and pS6 in gastric mucosa were significantly decreased in obese patients with $44.34 \pm 3.44 \mathrm{~kg} / \mathrm{m}^{2}$ body mass index (BMI) relative to lean human subjects (BMI $23.19 \pm 0.95 \mathrm{~kg} / \mathrm{m}^{2}$ ), while significantly increased in post-operative subjects (BMI $26.78 \pm 1.55 \mathrm{~kg} / \mathrm{m}^{2}$ ). In contrast to the changes in the pS6K and pS6, ghrelin mRNA (Fig. 7C) and protein (Fig. 7A) levels demonstrated a decrease in post-operative people compared to obese subjects. A significant negative correlation was determined between gastric levels of phospho-S6 and proghrelin (Pearson's $r=-0.7296 ; \mathrm{P}=$ 0.0006) (Fig. 7B).

Immunohistochemistry also showed that antibody recognizing phospho-S6 (Ser235/236) demonstrated stronger positive reactivity whereas ghrelin antibody produced weaker signal in gastric fundus of post-operative patients relative to obese subjects (Fig. 8). 


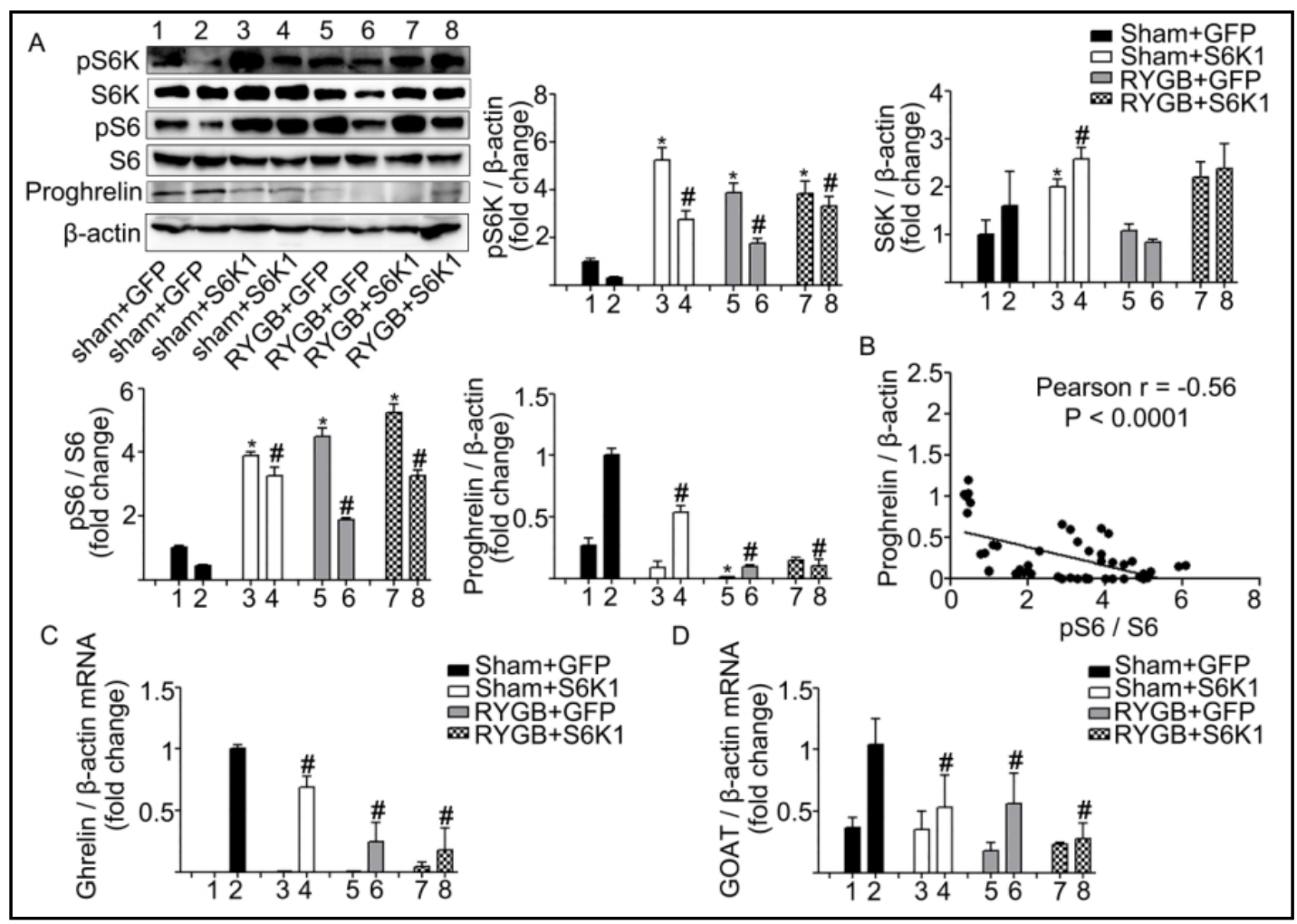

Fig. 5. Effects of RYGB on gastric mTORC1 signaling and ghrelin synthesis upon tail-vein administration of Ad-S6K1. (A) Representative western blot from sham- or RYGB-operated mice (4-5-month-old mice, $\mathrm{n}=$ 6) that received administration of Ad-GFP $\left(10^{9} \mathrm{pfu}\right)$ or Ad-S6K1 $\left(10^{9} \mathrm{pfu}\right)$. pS6K, S6K1, pS6 and proghrelin in gastric mucosa were detected using specific antibodies. S6 and $\beta$-actin were used as loading controls. Quantification of image analysis is expressed as mean values \pm SEM. (B) Correlation between protein levels of ghrelin and pS6 was determined by Pearson analysis. (C) and (D) Results of quantitative PCR analysis of ghrelin (C) and GOAT mRNA (D) are expressed as fold increase from control. ${ }^{*} \mathrm{P}<0.05$ vs. forestomachs from sham mice receiving Ad-GFP. " $\mathrm{P}<0.05$ vs. fundus from sham mice receiving Ad-GFP. Statistical differences were assessed by factorial design analysis of variance (ANOVA).

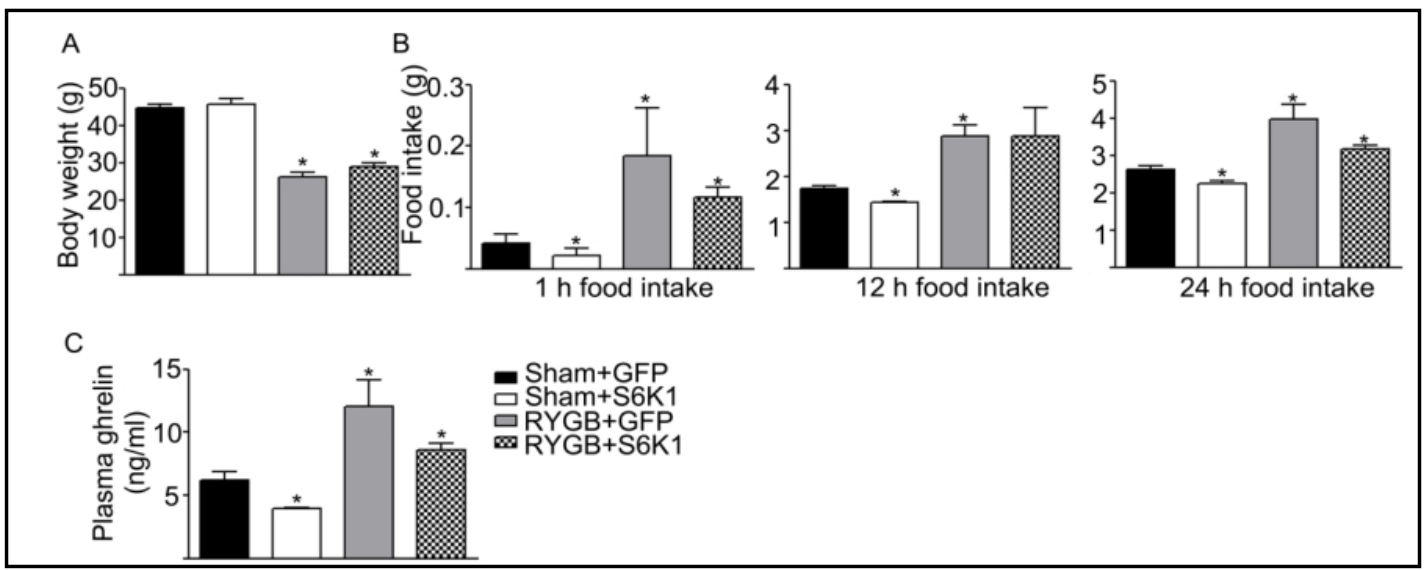

Fig. 6. Effects of Ad-S6K1 on RYGB-induced alteration of body weight, food intake and ghrelin secretion in DIO mice. (A) Body weight. (B) $1 \mathrm{~h}$ food intake in dark cycle, $12 \mathrm{~h}$ food intake in dark cycle and $24 \mathrm{~h}$ food intake. (C) Plasma total ghrelin in different group mice was measured as described in Materials and Methods, and results are expressed as mean values \pm SEM. $n=6,{ }^{*} \mathrm{P}<0.05$ vs. sham operated mice receiving Ad-GFP. Statistical differences were assessed by factorial design analysis of variance (ANOVA). 


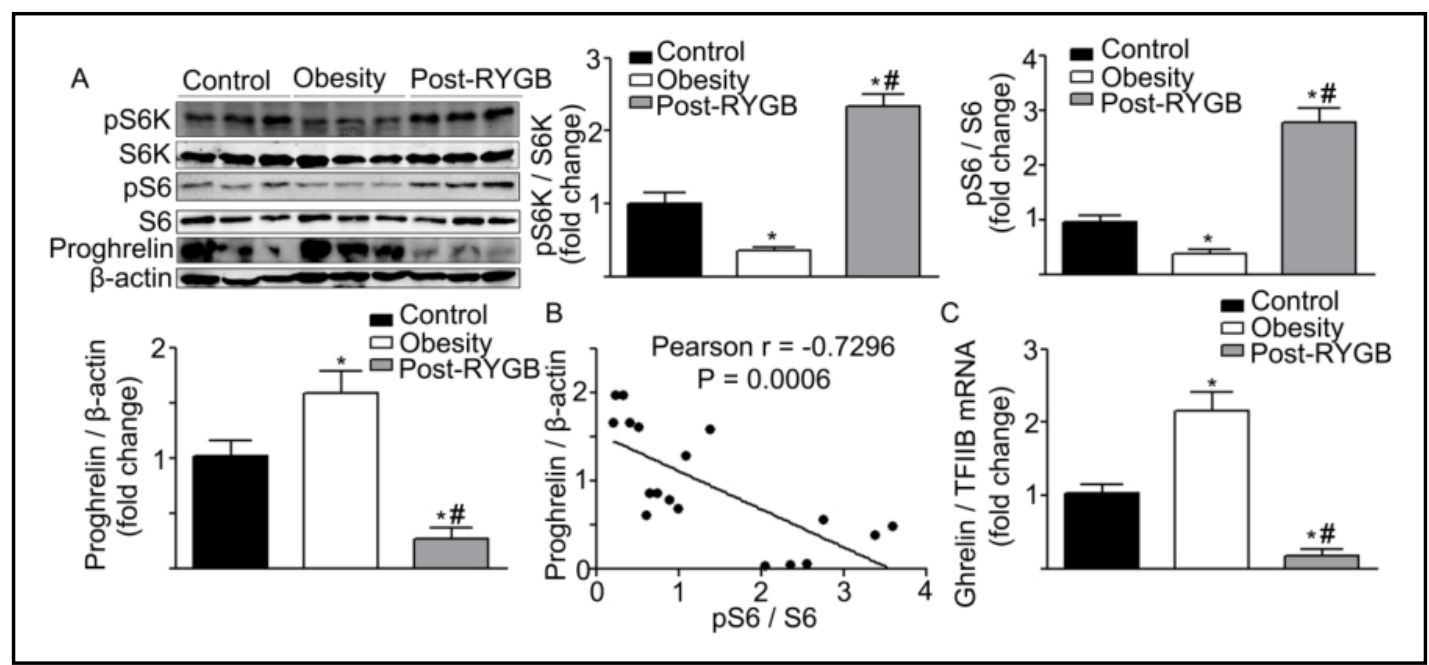

Fig. 7. Effects of RYGB on gastric mTOR signaling and ghrelin production in human beings. (A) Representative western blot from gastric fundus of lean, obese and one-year postoperative human subjects. pS6K, pS6 and proghrelin were blotted as described in Materials and Methods. S6K, S6 and $\beta$-actin were used as loading controls. Quantification of image analysis of gastric S6K, S6 phosphorylation and proghrelin expression is expressed as mean values \pm SEM. (B) Correlation between protein levels of ghrelin and pS6 was determined by Pearson analysis. (C) Results of quantitative PCR analysis of ghrelin mRNA are expressed as fold increase from lean subjects using TFIIB as a loading control. $\mathrm{n}=6$, ${ }^{*} \mathrm{P}<0.05$ vs. control subjects, ${ }^{\#} \mathrm{P}<0.05$ vs. obese subjects, Statistical differences were assessed by Mann-Whitney U rank sum test.

Fig. 8. Morphologic analysis of mTOR signaling and ghrelin production in obese and post-RYGB subjects. I $\mathrm{m} \mathrm{m} \mathrm{un} \mathrm{o} \mathrm{s} \mathrm{t} \mathrm{a} \mathrm{in} \mathrm{ing}$ of phospho-S6 (Ser235/236) and ghrelin in the human fundic mucosa. Upper panel, high-resolution images depicting ghrelin (green); lower panel, phospho-S6 (Ser235/236) (red) in gastric mucosal cells. Bar, $50 \mu \mathrm{m}$. Computerised image analysis (Model Leica Q550CW, Leica, Qwin, Germany) was performed to quantify the immunostaining signals of ghrelin and pS6 from human fundic mucosa. $\mathrm{n}=5, * \mathrm{P}<0.05$

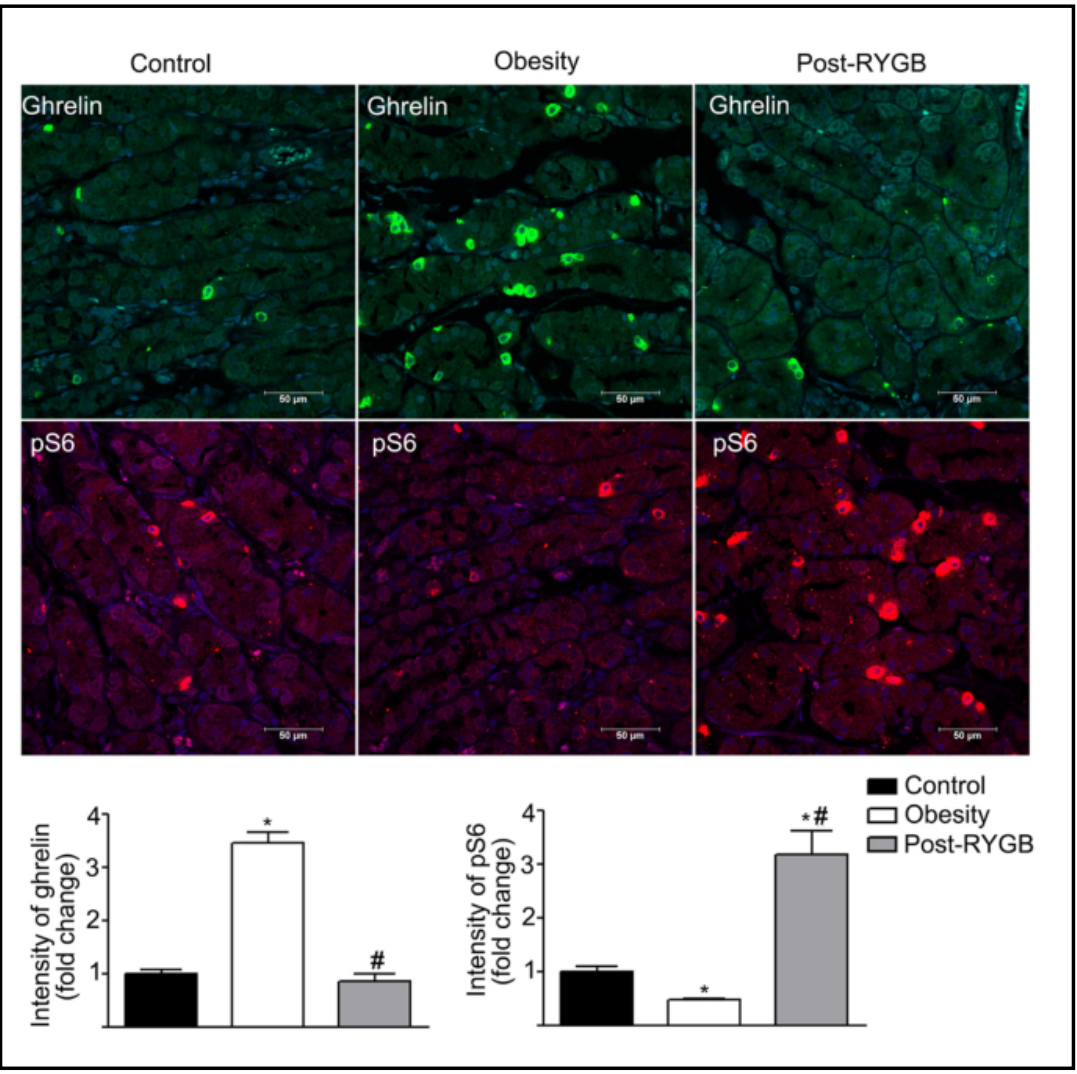
vs. control subjects, ${ }^{\#} \mathrm{P}<0.05$ vs. obese subjects, Statistical differences were assessed by Mann-Whitney U rank sum test. 


\section{Cellular Physiology Cell Physiol Biochem 2018;51:664-680

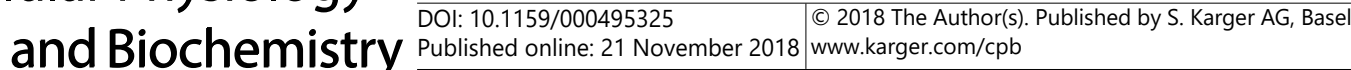 \\ Li et al.: Gastric mTORC1 Signaling and Ghrelin After RYGB}

\section{Discussion}

The major finding of the present study is that the mTOR signaling in gastric endocrine cells functions as a peripheral fuel sensor which contributes to inhibition of ghrelin synthesis induced by Roux-en-Y Gastric Bypass. This conclusion is supported by the following distinct observations: 1) a negative correlation exists between gastric mTOR signaling and the expression of ghrelin in different gastric segments during changes in energy status; 2) RYGB stimulates mTOR signaling in gastric fundus, which is associated with a significant decrease in the expression of ghrelin in both lean and obese mice; 3) alteration of mTOR signaling and ghrelin synthesis induced by rapamycin can be reversed by RYGB; 4) administration of Ad-S6K1 suppresses the ghrelin synthesis in RYGB-operated mice versus control mice; 5) consistent with the findings in mice, gastric mTOR activity is significantly increased and ghrelin expression is decreased in post-RYGB patients versus obese subjects.

The typical Roux-en-Y Gastric Bypass (RYGB) creates restriction of gastric volume and also causes food to bypass most of the stomach and a short segment of the proximal intestine, primarily the duodenum, leaving enough intact small bowel in digestive continuity to avoid clinically significant malabsorption $[8,9,39]$. RYGB causes weight loss through gastric restriction and additional mechanisms involving changes in gastrointestinal hormones that are under active investigation. Ghrelin, a gastric hormone, is initially synthesized within gastric $\mathrm{X} / \mathrm{A}$ like cells, which are mainly located in gastric fundus [16]. Gastric bypass is supposed to alter gastric ghrelin cell responsiveness. In our study, RYGB significantly inhibited ghrelin synthesis in both rodents and human subjects especially in gastric fundus, the main origin of ghrelin. The structure of ghrelin is unique in that specific acyl-modification of its third serine. This acylation is necessary for ghrelin to bind to GHSR-1a [40, 41]. Our data also showed ghrelin 0-acyltransferase (GOAT) mRNA level in RYGB-operated mice was significantly lower than sham-operated group. Rapamycin enhanced while Ad-S6K1 inhibited GOAT expression in sham mice but not in RYGB-operated animals.

Direct control of ghrelin expression and secretion can occur at the level of gastric mucosa. Our previous studies indicate that gastric mTOR signaling regulates ghrelin production and food intake. In present study we firstly reported that mTOR activity in forestomachs was significantly higher than in gastric fundus, while ghrelin was mainly expressed in fundus. A significant negative correlation was found between mTOR signaling activity and ghrelin expression. Moreover, restricted ghrelin expression in both gastric pouches and residual stomachs was observed in RYGB-operated mice. Decreased ghrelin expression in residual stomachs after RYGB may be explained by activated mTOR signaling. To the best of our knowledge, this is the first report that shows the change of gastric mTOR signaling activity and its effects on ghrelin synthesis after RYGB in rodents. According to our study, rapamycin can't completely block the effects of RYGB on ghrelin synthesis. It is worth of noting that signaling pathway in addition to mTOR may mediate the effects of RYGB surgery on ghrelin. Further studies on other signaling pathways will address this potential.

Prader-Willi Syndrome (PWS) is a chromosomal disorder characterized by the presence of hyperghrelinemia, hyperphagia, and obesity. Significant reduction of body weight and the level of serum ghrelin can be achieved after gastric Mini-Bypass for Prader-Willi Syndrome patients [42]. The current study examined potential mechanisms for altered gastric ghrelin levels observed in obese and post-RYGB operative subjects. We report here both ghrelin mRNA and protein levels were significantly decreased in post-RYGB patients compared to obese people. Moreover, the present study also described that phosphorylation of S6K and S6, the downstream targets of mTOR, in gastric endocrine cells of post-RYGB subjects was activated. Hyperactivated mTOR pathway may play a critical role in the inhibition of ghrelin expression experienced by most participants undergoing RYGB. The significant alterations in gastric mTOR activity and expression of ghrelin described in this study may help to understand some of the mechanisms behind the well-documented changes in body weight and glycemic levels after RYGB in human beings. Ghrelin is regarded as an orexigenic hormone that is able to induce the sensation of hunger and to stimulate appetite via a mechanism involving the 
Fig. 9. Summary of putative mechanisms linking mTORC1 signaling pathway and ghrelin production after Roux-en-Y gastric bypass. After RYGB, gastric mTOR signaling is elevated, which contributes to the inhibition of ghrelin expression especially in residual stomach.

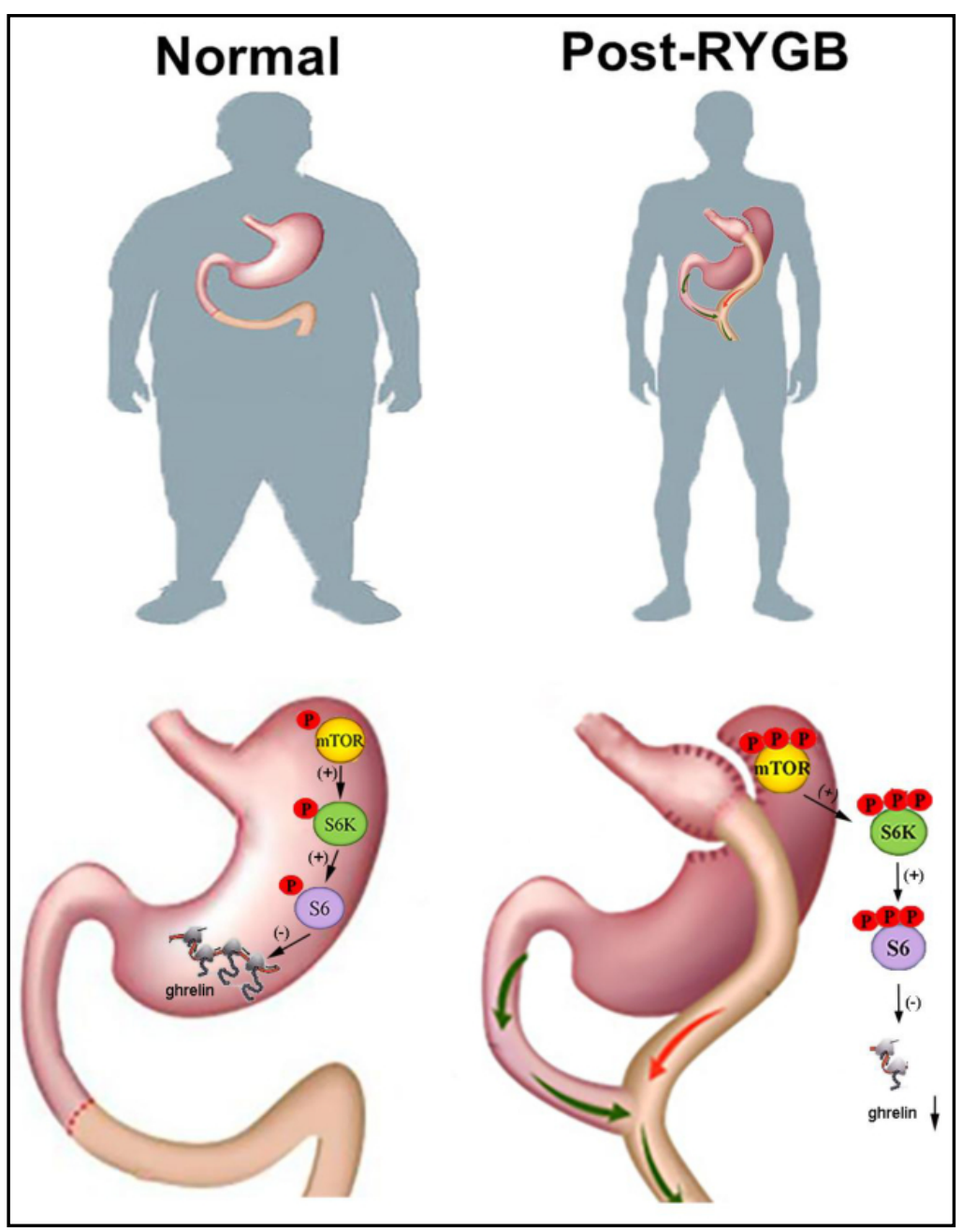

central nervous system [43-46]. Ghrelin acts as a stomach derived hormone that functions in conjunction with other peripheral signals such as leptin and insulin [47-49]. Ghrelin is a brain-gut peptide that modulates both orexigenic neuropeptide $\mathrm{Y} /$ agouti-related peptide neurons and anorexigenic proopiomelanocortin neurons [50]. Consistent to previous studies [34, 36], here we show total ghrelin secretion is significantly higher in RYGB mice at 4 weeks after surgery. Moreover, the change of serum ghrelin is associated with mouse food intake (as shown in Fig. 4 and 6). The stimulation of food intake in post RYGB-mice may also be explained by increased mRNA levels of orexigenic AgRP and NPY in the arcuate nucleus according to Barkholt's study [51]. Roux-en-Y Gastric Bypass is associated with an increased risk of postprandial hyperinsulinaemic hypoglycaemia [52]. We speculate that the severe postprandial hypoglycaemia after RYGB might be rescued by the enhancement of post-operative circulating ghrelin level in mice.

In addition to its appetite-stimulating effect, ghrelin plays a vital role in the regulation of insulin secretion [53]. Previous studies have demonstrated that ghrelin is able to inhibit insulin release in islets [26], pancreatic cell lines [54, 55] and perfused rat pancreas [56]. GHSR-1a antagonism or antiserum against acylated ghrelin significantly increases insulin secretion from perfused pancreas [26]. In addition, ghrelin contributes to derangements of glucose metabolism induced by rapamycin via altering the content and translocation of GLUT4 in muscles [57]. Since ghrelin is an orexigenic and hyperglycemic hormone, the inhibition of origin of ghrelin may somehow explain weight loss and hypoglycemic effects induced by RYGB operation. 


\section{Cellular Physiology Cell Physiol Biochem 2018;51:664-680 and Biochemistry \begin{tabular}{l|l} 
DOI: 10.1159/000495325 & (c) 2018 The Author(s). Published by S. Karger AG, Basel \\
www.karger.com/cpb
\end{tabular}

\section{Conclusion}

In summary, our studies demonstrate that RYGB activates mTORC1signaling to inhibit ghrelin production in gastric X/A like cells (Fig. 9). By investigating the function of the gastric mTOR pathway in postoperative ghrelin production, we propose that restoring the homeostasis of the gastrointestinal endocrine and fuel sensing network is necessary for a safe and effective therapy in the setting of obesity and diabetes by "pharmaceutical gastric bypass".

\section{Abbreviations}

Ad-GFP (adenovirus-mediated green fluorescent protein); Ad-S6K1 (adenovirusmediated p70 ribosomal protein subunit 6 kinase 1); DIO (diet-induced obese); DMSO (dimethyl sulfoxide); GHSR-1a (growth hormone secretagogue receptor 1a); GOAT (ghrelin O-acyltransferase; i.p., intraperitoneal); mTOR (mammalian target of rapamycin); RYGB (Roux-en-Y Gastric Bypass); S6 (ribosomal protein S6); S6K1 (p70 ribosomal protein subunit 6 kinase 1).

\section{Acknowledgements}

We thank Dr. Weizhen Zhang (Department of Physiology and Pathophysiology, Peking University Health Science Center, Beijing, China) for providing Ad-S6K1 and AdGFP adenovirus. This work was supported by the National Natural Science Foundation of China [grant numbers 81770794, 31401001]; the Science and Technology Planning Project of Guangdong Province, China [grant numbers 2014A020212210]; the Natural Science Foundation of Guangdong Province [grant numbers 2016A030310086]; the Special Grants from the Guangzhou Pearl River Young Talents of Science and Technology [grant numbers 201610010079]; and the Fundamental Research Funds for the Central Universities [grant numbers 21617457].

\section{Disclosure Statement}

The authors declared that they have no conflicts of interest related to this work.

\section{References}

1 Bhupathiraju SN, Hu FB: Epidemiology of obesity and diabetes and their cardiovascular complications. Circ Res 2016;118:1723-1735.

-2 Pories WJ, Swanson MS, MacDonald KG, Long SB, Morris PG, Brown BM, Barakat HA, deRamon RA, Israel G, Dolezal JM: Who would have thought it? An operation proves to be the most effective therapy for adultonset diabetes mellitus. Ann Surg 1995;222:339-350.

3 Buchwald H, Avidor Y, Braunwald E, Jensen MD, Pories W, Fahrbach K, Schoelles K: Bariatric surgery: a systematic review and meta-analysis. JAMA 2004;292:1724-1737.

4 Cohen RV, Pinheiro JC, Schiavon CA, Salles JE, Wajchenberg BL, Cummings DE: Effects of gastric bypass surgery in patients with type 2 diabetes and only mild obesity. Diabetes care 2012;35:1420-1428.

5 Nguyen NT, Masoomi H, Magno CP, Nguyen XMT, Laugenour K, Lane J: Trends in use of bariatric surgery, 2003-2008. J Am Coll Surg 2011;213:261-266.

6 Kushner RF: Weight loss strategies for treatment of obesity. Prog Cardiovasc Dis 2014;56:465-472. 


\section{Cellular Physiology Cell Physiol Biochem 2018;51:664-680

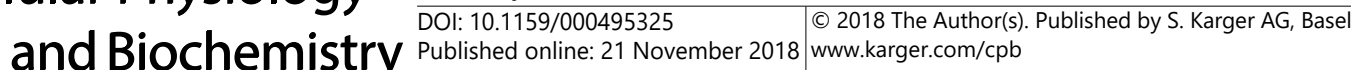

Li et al.: Gastric mTORC1 Signaling and Ghrelin After RYGB

7 Gray KD, Moore MD, Bellorin O, Abelson JS, Dakin G, Zarnegar R, Pomp A, Afaneh C: Increased Metabolic Benefit for Obese, Elderly Patients Undergoing Roux-en-Y Gastric Bypass vs Sleeve Gastrectomy. Obes Surg 2018;28:636-642.

-8 Griffen WO Jr, Young VL, Stevenson CC: A prospective comparison of gastric and jejunoileal bypass procedures for morbid obesity. Ann Surg 1977;186:500-509.

-9 Wittgrove AC, Clark GW, Tremblay LJ: Laparoscopic gastric bypass, Roux-en-Y: preliminary report of five cases. Obes Surg 1994;4:353-357.

$\$ 10$ Cummings DE, Overduin J, Shannon MH, Foster-Schubert KE: Hormonal mechanisms of weight loss and diabetes resolution after bariatric surgery. Surg Obes Relat Dis 2005;1:358-368.

-11 Jacobsen SH, Olesen SC, Dirksen C, Jørgensen NB, Bojsen-Møller KN, Kielgast U, Worm D, Almdal T, Naver LS, Hvolris LE, Rehfeld JF, Wulff BS, Clausen TR, Hansen DL, Holst JJ, Madsbad S: Changes in gastrointestinal hormone responses, insulin sensitivity, and beta-cell function within 2 weeks after gastric bypass in nondiabetic subjects. Obes Surg 2012;22:1084-1096.

-12 Dirksen C, Jørgensen NB, Bojsen-Møller KN, Kielgast U, Jacobsen SH, Clausen TR, Worm D, Hartmann B, Rehfeld JF, Damgaard M, Madsen JL, Madsbad S, Holst JJ, Hansen DL: Gut hormones, early dumping and resting energy expenditure in patients with good and poor weight loss response after Roux-en-Y gastric bypass. Int J Obes 2013;37:1452-1459.

13 Steiner RE, Feinle-Bisset C, Asarian L, Horowitz M, Beglinger C, Geary N: Ghrelin, CCK, GLP-1, and PYY (3-36): secretory controls and physiological roles in eating and glycemia in health, obesity, and after RYGB. Physiol Rev 2016;97:411-463.

14 Tymitz K, Engel A, McDonough S, Hendy MP, Kerlakian G: Changes in ghrelin levels following bariatric surgery: review of the literature. Obes Surg 2011;21:125-130.

15 Kojima M, Hosoda H, Date Y, Nakazato M: Ghrelin is a growth-hormone-releasing acylated peptide from stomach. Nature 1999;402:656-660.

16 Ariyasu H, Takaya K, Tagami T, Ogawa Y, Hosoda K, Akamizu T, Suda M, Koh T, Natsui K, Toyooka S, Shirakami G, Usui T, Shimatsu A, Doi K, Hosoda H, Kojima M, Kangawa K, Nakao K: Stomach is a major source of circulating ghrelin, and feeding state determines plasma ghrelin-like immunoreactivity levels in humans. J Clin Endocrinol Metab 2001;86:4753-4758.

17 Date Y, Kojima M, Hosoda H, Sawaguchi A, Mondal MS, Suganuma T, Matsukura S, Kangawa K, Nakazato M: Ghrelin, a Novel Growth Hormone-Releasing Acylated Peptide, Is Synthesized in a Distinct Endocrine Cell Type in the Gastrointestinal Tracts of Rats and Humans. Endocrinology 2000;141:4255-4261.

18 Gutierrez JA, Solenberg PJ, Perkins DR, Willency JA, Knierman MD, Jin Z, Witcher DR, Luo S, Onyia JE, Hale JE: Ghrelin octanoylation mediated by an orphan lipid transferase. Proc Natl Acad Sci 2008;105:6320-6325.

19 Yang J, Brown MS, Liang G, Grishin NV, Goldstein JL: Identification of the acyltransferase that octanoylates ghrelin, an appetite-stimulating peptide hormone. Cell 2008;132:387-396.

20 Delhanty PJ, Neggers SJ, van der Lely AJ: Mechanisms in endocrinology: Ghrelin: the differences between acyl-and des-acyl ghrelin. Eur J Endocrinol 2012;167:601-608.

-21 Müller TD, Nogueiras R, Andermann ML, Andrews ZB, Anker SD, Argente J, Batterham RL, Benoit SC, Bowers CY, Broglio F, Casanueva FF, D’Alessio D, Depoortere I, Geliebter A, Ghigo E, Cole PA, Cowley M, Cummings DE, Dagher A, Diano S, Dickson SL, et al.: Ghrelin. Mol Metab 2015;4:437-460.

22 Nakazato M, Murakami N, Date Y, Kojima M, Matsuo H, Kangawa K, Matsukura S: A role for ghrelin in the central regulation of feeding. Nature 2001;409:194-198.

23 Wang Q, Liu C, Uchida A, Chuang JC, Walker A, Liu T, Osborne-Lawrence S, Mason BL, Mosher C, Berglund ED, Elmquist JK, Zigman JM: Arcuate AgRP neurons mediate orexigenic and glucoregulatory actions of ghrelin. Mol Metab 2014;3:64-72.

24 Tschöp M, Smiley DL, Heiman ML: Ghrelin induces adiposity in rodents. Nature 2000;407:908-913.

-25 Wren AM, Small CJ, Abbott CR, Dhillo WS, Seal LJ, Cohen MA, Batterham RL, Taheri S, Stanley SA, Ghatei MA, Bloom SR: Ghrelin causes hyperphagia and obesity in rats. Diabetes 2001;50:2540-2547.

26 Dezaki K, Hosoda H, Kakei M, Hashiguchi S, Watanabe M, Kangawa K, Yada T: Endogenous ghrelin in pancreatic islets restricts insulin release by attenuating $\mathrm{Ca}^{2+}$ signaling in $\beta$-cells: implication in the glycemic control in rodents. Diabetes 2004;53:3142-3151.

-27 Yada T, Damdindorj B, Rita RS, Kurashina T, Ando A, Taguchi M, Koizumi M, Sone H, Nakata M, Kakei M, Dezaki K: Ghrelin signalling in $\beta$-cells regulates insulin secretion and blood glucose. Diabetes Obes Metab 2014;16:111-117. 


\section{Cellular Physiology Cell Physiol Biochem 2018;51:664-680 and Biochemistry \begin{tabular}{l|l} 
DOI: 10.1159/000495325 & (c) 2018 The Author(s). Published by S. Karger AG, Basel \\
www.karger.com/cpb
\end{tabular}}

Li et al.: Gastric mTORC1 Signaling and Ghrelin After RYGB

28 Cummings DE, Purnell JQ, Frayo RS, Schmidova K, Wisse BE, Weigle DS: A preprandial rise in plasma ghrelin levels suggests a role in meal initiation in humans. Diabetes 2001;50:1714-1719.

29 Tschöp M, Weyer C, Tataranni PA, Devanarayan V, Ravussin E, Heiman ML: Circulating ghrelin levels are decreased in human obesity. Diabetes 2001;50:707-709.

-30 Williams DL, Grill HJ, Cummings DE, Kaplan JM: Overfeeding-induced weight gain suppresses plasma ghrelin levels in rats. J Endocrinol Invest 2006;29:863-868.

31 Xu G, Li Y, An W, Li S, Guan Y, Wang N, Tang C, Wang X, Zhu Y, Li X, Mulholland MW, Zhang W: Gastric mammalian target of rapamycin signaling regulates ghrelin production and food intake. Endocrinology 2009;150:3637-3644.

-32 Albert V, Hall MN: mTOR signaling in cellular and organismal energetics. Curr Opin Cell Biol 2015;33:5566.

-33 Laplante M, Sabatini DM: mTOR signaling in growth control and disease. Cell 2012;149:274-293.

-34 Hao Z, Zhao Z, Berthoud HR, Ye J: Development and verification of a mouse model for Roux-en-Y gastric bypass surgery with a small gastric pouch. PloS One 2013;8:e52922.

35 Bruinsma BG, Uygun K, Yarmush ML, Saeidi N: Surgical models of Roux-en-Y gastric bypass surgery and sleeve gastrectomy in rats and mice. Nat Protoc 2015;10:495-507.

36 Uchida A, Zechner JF, Mani BK, Park WM, Aguirre V, Zigman JM: Altered ghrelin secretion in mice in response to diet-induced obesity and Roux-en-Y gastric bypass. Mol Metab 2014;3:717-730.

-37 Pullen N, Thomas G: The modular phosphorylation and activation of p70s6k. FEBS Lett 1997;410:78-82.

38 Jenö P, Ballou LM, Novak-Hofer I, Thomas G: Identification and characterization of a mitogen-activated S6 kinase. Proc Natl Acad Sci 1988;85:406-410.

-39 Cummings DE: Endocrine mechanisms mediating remission of diabetes after gastric bypass surgery. Int J Obes 2009;33:S33-40.

$>40$ Hosoda H, Kojima M, Matsuo H, Kangawa K: Ghrelin and des-acyl ghrelin: two major forms of rat ghrelin peptide in gastrointestinal tissue. Biochem Biophys Res Commun 2000;279:909-913.

41 Zhu X, Cao Y, Voodg K, Steiner DF: On the processing of proghrelin to ghrelin. J Biol Chem 2006;281:3886738870.

-42 Fong AK, Wong SK, Lam CC, Ng EK: Ghrelin level and weight loss after laparoscopic sleeve gastrectomy and gastric mini-bypass for Prader-Willi syndrome in Chinese. Obes Surg 2012;22:1742-1745.

43 Toshinai K, Date Y, Murakami N, Shimada M, Mondal MS, Shimbara T, Guan JL, Wang QP, Funahashi H, Sakurai T, Shioda S, Matsukura S, Kangawa K, Nakazato M: Ghrelin-induced food intake is mediated via the orexin pathway. Endocrinology 2003;144:1506-1512.

44 Abizaid A, Liu ZW, Andrews ZB, Shanabrough M, Borok E, Elsworth JD, Roth RH, Sleeman MW, Picciotto MR, Tschöp MH, Gao XB, Horvath TL: Ghrelin modulates the activity and synaptic input organization of midbrain dopamine neurons while promoting appetite. J Clin Invest 2006;116:3229-3239.

-45 Wren AM, Seal LJ, Cohen MA, Brynes AE, Frost GS, Murphy KG, Dhillo WS, Ghatei MA, Bloom SR: Ghrelin enhances appetite and increases food intake in humans. J Clin Endocrinol Metab 2001;86:5992.

-46 Wren AM, Small CJ, Ward HL, Murphy KG, Dakin CL, Taheri S, Kennedy AR, Roberts GH, Morgan DG, Ghatei MA, Bloom SR: The novel hypothalamic peptide ghrelin stimulates food intake and growth hormone secretion. Endocrinology 2000;141:4325-4328.

47 Murdolo G, Lucidi P, Di Loreto C, Parlanti N, De Cicco A, Fatone C, Fanelli CG, Bolli GB, Santeusanio F, De Feo $P$ : Insulin is required for prandial ghrelin suppression in humans. Diabetes 2003;52:2923-2927.

48 Palou M, Sánchez J, Rodríguez AM, Priego T, Picó C, Palou A: Induction of NPY/AgRP orexigenic peptide expression in rat hypothalamus is an early event in fasting: relationship with circulating leptin, insulin and glucose. Cell Physiol Biochem 2009;23:115-124.

49 Ueno N, Dube MG, Inui A, Kalra PS, Kalra SP: Leptin modulates orexigenic effects of ghrelin and attenuates adiponectin and insulin levels and selectively the dark-phase feeding as revealed by central leptin gene therapy. Endocrinology 2004;145:4176-4184.

50 Chen HY, Trumbauer ME, Chen AS, Weingarth DT, Adams JR, Frazier EG, Shen Z, Marsh DJ, Feighner SD, Guan XM, Ye Z, Nargund RP, Smith RG, Van der Ploeg LH, Howard AD, MacNeil DJ, Qian S: Orexigenic action of peripheral ghrelin is mediated by neuropeptide $Y$ and agouti-related protein. Endocrinology 2004;145:2607-2612.

51 Barkholt P, Pedersen PJ, Hay-Schmidt A, Jelsing J, Hansen HH, Vrang N: Alterations in hypothalamic gene expression following Roux-en-Y gastric bypass. Mol Metab 2016;5:296-304. 


\section{Cellular Physiology Cell Physiol Biochem 2018;51:664-680

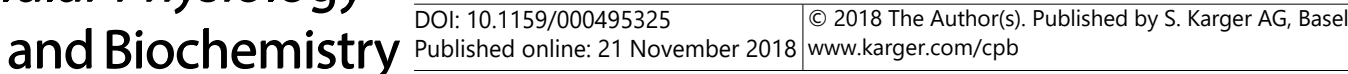

Li et al.: Gastric mTORC1 Signaling and Ghrelin After RYGB

52 Vaurs C, Brun JF, Bertrand M, Burcelin R, du Rieu MC, Anduze Y, Hanaire H, Ritz P: Post-prandial hypoglycemia results from a non-glucose-dependent inappropriate insulin secretion in Roux-en-Y gastric bypassed patients. Metabolism 2016:65:18-26.

53 Dezaki K, Sone H, Koizumi M, Nakata M, Kakei M, Nagai H, Hosoda H, Kangawa K, Yada T: Blockade of pancreatic islet-derived ghrelin enhances insulin secretion to prevent high-fat diet-induced glucose intolerance. Diabetes 2006;55:3486-3493.

54 Doi A, Shono T, Nishi M, Furuta H, Sasaki H, Nanjo K: IA-2 $\beta$, but not IA-2, is induced by ghrelin and inhibits glucose-stimulated insulin secretion. Proc Natl Acad Sci 2006;103:885-890.

-55 Wang Y, Nishi M, Shono T, Furukawa Y, Shimada T, Furuta H, Sasaki H, Nanjo K: Ghrelin inhibits insulin secretion through the AMPK-UCP2 pathway in $\beta$ cells. FEBS Lett 2010;584:1503-1508.

56 Egido EM, Rodriguez-Gallardo J, Silvestre RA, Marco J: Inhibitory effect of ghrelin on insulin and pancreatic somatostatin secretion. Eur J Endocrinol 2002;146:241-244.

57 Xu G, Wang Z, Li Y, Li Z, Tang H, Zhao J: Ghrelin contributes to derangements of glucose metabolism induced by rapamycin in mice. Diabetologia 2012;55:1813-1823. 